\title{
Sistem Pakar Mendiagnosis Penyakit Pada Tanaman Mentimun menggunakan Metode Dempster Shafer Berbasis Android
}

\author{
Syaiful Amri ${ }^{1 *}$, R. Fanri Siahaan ${ }^{2}$ \\ ${ }^{1,2}$ STMIK Pelita Nusantara \\ Jl. Iskandar Muda No. 1 Medan 20154 Indonesia \\ Corresponding author‘s e-mail: syaifulamri6615@gmail.com
}

\begin{abstract}
Abstrak - Teknologi informasi hampir tidak dapat dilepaskan dari berbagai aspek kehidupan manusia, dikarenakan kemudahan untuk mengakses informasi adalah salah satu pemanfaatannya. Minimnya pakar tumbuhan dan pengetahuan petani dalam menangani penyakit pada tanaman mentimun menyebabkan kerugian bagi petani khususnya petani mentimun. Selain daripada itu hal ini juga menjadi hambatan bagi para petani mentimun untuk mendiagnosa dan melakukan penanganan yang tepat terhadap penyakit mentimun yang menyerang tanaman yang mereka tanam. Petani kurang paham terhadap jenis penyakit pada tanaman mentimun, sehingga lambatnya proses penanganan pada tanaman mentimun. Dempster-Shafer dikenal adanya Frame of Discrement yang dinotasikan dengan dengan $\theta$. Frame ini merupakan semesta pembicaraan dari sekumpulan hipotesis.Sistem pakar umumnya didefinisikan sebagai sebuah sistem yang dirancang untuk memodelkan kemampuan menyelesaikan masalah seperti layaknya seorang pakar (human expert). Identifikasi masalah dalam penelitian ini yaitu kerusakan pada tanaman mentimun akibat sulitnya mengidentifikasi penyakit pada tanaman mentimun. ruang lingkup/batasan masalah dalam penelitian ini Data penyakit yang akan diteliti sebanyak 6 penyakit, data gejala yang akan diteliti sebanyak 12 gejala. Metode yang digunakan dalam mendiagnose penyakit pada tanaman mentimun ialah metode Dempster Shafer. Aplikasi yang digunakan adalah aplikasi Adobe Animate CC. Database yang digunakan adalah SQLite.
\end{abstract}

Kata kunci: Penyakit Timun, Android, Sistem Pakar, Dempster Shafer

Abstract - Information technology can hardly be separated from various aspects of human life, because the ease of accessing information is one of its uses. Farmers do not understand the types of diseases in cucumber plants, so the process of handling cucumber plants is slow. Dempster-Shafer is known for its Frame of Discrement which is denoted by $\theta$. This frame is a universe of discussion from a set of hypotheses. An expert system is generally defined as a system designed to model problem-solving abilities like a human expert. Identification of the problem in this study is damage to cucumber plants due to the difficulty of identifying diseases in cucumber plants. the scope / limitation of the problem in this study. The disease data to be studied were 6 diseases, the symptom data to be studied were 12 symptoms. The method used in diagnosing diseases in cucumber plants is the Dempster Shafer method. The application used is the Adobe Animate CC application. The database used is SQLite.

Keywords: Cucumber Disease, Android, Expert System, Dempster Shafer

\section{Pendahuluan}

Sulitnya mendapatkan informasi tentang jenis penyakit, gejala penyakit, bagaimana merawat tanaman mentimun, dan bagaimana memilih tindakan yang tepat untuk penanganan penyakit pada tanaman mentimun. Dalam hal ini peran seorang expert (pakar) sangat diandalkan untuk pengendalian dan menentukan jenis penyakit yang menyerang serta memberikan contoh cara pengendalian guna mendapatkan solusi terbaik. Keterbatasanyang dimiliki seorang expert (pakar) terkadang menjadi kendala bagi para petani yang akan melakukan konsultasi guna menyelesaikan suatu permasalahan untuk mendapat solusi terbaik. Dalam hal ini sistem pakar dihadirkan sebagai alternatif kedua dalam memecahkan permasalahan setelah seorang expert (pakar) [1]. Perancangan sistem pakar yang dibuat yaitu berbasis Android sehingga petani dapat dengan mudah berkonsultasi dimana saja asalkan Android terkoneksi dengan internet. Metode inferensi yang digunakan dalam pembuatan sistem ini yaitu Metode Dempster shafer. Android sendiri adalah sistem operasi berbasis linux yang dirancang untuk perangkat bergerak layar sentuh seperti telepon pintar dan komputer tablet [2].

Metode Dempster shafer adalah suatu teori matematika untuk pembuktian berdasarkan belif functions and plausible reasoning (fungsi kepercayaan dan pemikiran yang masuk akal), yang digunakan untuk mengkombinasikan potongan informasi yang terpisah (bukti) untuk mengkalkulasi kemungkinan dari suatu peristiwa. Dempster Shafer merupakan generalisasi dari teori Bayesian probabilitas subjektif dengan kebutuhan probabilitas yang akan dibutuhkan untuk setiap pertanyaan dari keinginan, fungsi kepercayaan berdasarkan pada tingkat kepercayaan (percaya diri atau percaya) untuk sebuah pertanyaan dalam probabilitas untuk sebuah pertanyaan tertentu [3]. Penelitian Perancangan Sistem Pakar Diagnosis Penyakit Ginjal 
Menggunakan Metode Dempster-Shafer Berbasis Website menguraikan Dempster-shafer ditulis dalam bentuk [Belief, Plausibility]. Belief bertujuan untuk menunjukkan suatu ukuran dari kekuatan evidance (gejala) dalam menunjang suatu hasil hipotesis, jika bernilai 0 menunjukkan tidak adanya evidance (gejala), dan jika bernilai 1 menunjukkan adanya kepastian [4].

Penelitian Sistem Pakar Diagnosa Penyakit Tanaman Semangka Menggunakan Metode Dempster Shafer Berbasis Web menjelaskan Kerangka shafer's dapat memberikan kepercayaan mengenai proposi untuk dapat direpresentasikan sebagai interval, diliputi dengan 2 buah nilai, kepercayaan (atau dukungan) dan hal yang masuk akal, belief $\leq$ plausibility [5]. Penelitian Perancangan Sistem Pakar Diagnosa Penyakit Pada Bayi Menggunakan Metode Dempster Shafer menjelaskan Sistem pakar (expert system) merupakan sistem yang mengadopsi pola pikir dari pakar untuk selanjutnya diterapkan ke dalam sebuah software, supaya komputer dapat menyelesaikan permasalahan seperti halnya yang sudah terbiasa dilakukan oleh ahli atau pakar [6].

\section{Tinjauan Pustaka}

\subsection{Sistem Pakar (Expert System)}

Sistem pakar adalah aplikasi berbasis komputer yang digunakan untuk menyelesaikan masalah sebagaimana yang dipikirkan oleh pakar. Pakar yang dimaksud disini adalah orang yang mempunyai keahlian khusus yang dapat menyelesaikan masalah yang tidak dapat diselesaikan oleh orang awam [7]. Sebagai contoh, dokter adalah seorang pakar yang mampu mendiagnosis penyakit yang diderita pasien serta dapat memberikan penata laksanaan terhadap penyakit tersebut. Sistem pakar adalah program artificial intellegence yang menggabungkan pangkalan pengetahuan (Knowledge Base) dengan sistem inferensi. Ini merupakan bagian software spesialisasi tingkat tinggi yang berusaha menduplikasi fungsi seorang pakar dalam satu bidang keahlian. Program ini bertindak sebagai seorang konsultan yang cerdas atau penasihat dalam suatu lingkungan keahlian tertentu, sebagai hasil himpunan pengetahuan yang telah dikumpulkan dari beberapa orang pakar [8].

\subsection{Metode Dempster-Shafer}

Metode Dempster-Shafer pertama kali diperkenalkan oleh Dempster, yang melakukan percobaan model ketidakpastian dengan range probabilities dari pada sebagai probabilitas tunggal [9]. Kemudian pada tahun 1976 Shafer mempublikasikan teori Dempster itu pada sebuah buku yang berjudul Mathematical Theory of Evident.' Dempster-Shafer Theory Of Evidence, menunjukkan suatu cara untuk memberikan bobot keyakinan sesuai fakta yang dikumpulkan [10]. Pada teori ini memiliki beberapa karakteristik yang secara instutitif sesuai dengan cara berfikir seorang pakar, namum memiliki dasar matematika yang kuat. Secara umum teori Dempster-Shafer ditulis dalam suatu interval [11]:

[Belif, \{lausiblity] ...

Belief (Bel) adalah ukuran kekuatan evidence dalam mendukung suatu himpunan proposisi. Jika bernilai 0 maka mengindifikasikan bahwa tidak ada evidence, dan jika 1 menunjukkan adanya kepastian.

Plausiblity (p1) dinotasikan sebagai :

$\mathrm{P} 1(\mathrm{~s})=1-\operatorname{Bel}(\ulcorner\mathrm{s})$

Plausiblity juga bernilai 0 sampai 1 . Jika yang akan $\left\ulcorner^{\text {s }}\right.$, maka dapat dikatakan bahwa Bel $(\ulcorner$ s) $=1$, dan P1 $(\ulcorner\mathrm{s})=0$.

\section{Metode Penelitian}

Metode penelitian, sebagai berikut:

1. Analisa Masalah, sekumpulan kegiatan, aktivitas dan proses yang saling berkaitan untuk memecahkan masalah atau memecahkan komponen menjadi lebih detail dan digabungkan kembali lalu ditarik kesimpulan.

2. Pengumpulan data

Merupakan kegiatan mencari data di lapangan yang akan digunakan untuk menjawab permasalahan penelitian. Validitas instrumen pengumpulan data serta kualifikasi pengumpul data sangat diperlukan untuk memperoleh data yang berkualitas.

3. Analisis Data, upaya atau cara untuk mengolah data menjadi informasi sehingga karakteristik data tersebut bisa dipahami dan bermanfaat untuk solusi permasalahan.

4. Proses Metode Dempster Shafer

Dempster-Shafer merupakan teori matematika yang berdasarkan pada belief functions dan plausible reasoning. Teori ini bekerja dengan menggabungkan beberapa informasi atau fakta yang ada untuk dihitung dan menghasilkan kesimpulan berupa kemungkinan terjadinya suatu peristiwa. Fungsi belief dan plausability, dalam teori Dempster-Shafer juga dikenal istilah mass function dan ditulis dengan notasi m. 
Mass function digunakan untuk mendapatkan nilai kepercayaan dari gabungan sejumlah gejala. Teori Dempster-Shafer ini sudah digunakan untuk kasus diagnosa penyakit, karena dapat menangani uncertainty dengan mencari hal yang masuk akal.

5. Perancangan sistem, desain sistem menentukan bagaimana suatu sistem akan menyelesaikan apa yang mesti diselesaikan, tahap ini menyangkut mengkonfigurasikan dari komponen-komponen perangkat lunak dan perangkat keras dari suatu sistem sehingga setelah instalasi dari sistem akan benar benar memuaskan rancang bangun yang telah ditetapkan pada akhir analisis sistem.

6. Implementasi Sistem, tahap penerapan sistem yang akan dilakukan jika sistem disetujui termasuk program yang telah dibuat pada tahap perancangan sistem agar siap untuk dioperasikan.

7. Pengujian Sistem, pengujian program perangkat lunak yang lengkap dan terintegrasi. Biasanya, perangkat lunak dihubungkan dengan perangkat lunak dan perangkat keras lainnya. Dalam langkah ini dilakukan pengujian aplikasi berjalan dengan baik atau tidak. Aplikasi ini akan dilakukan 3 kali pengujian yaitu uji validasi teori untuk mengetahui kebenaran basis pengetahuan dalam aplikasi, uji blackbox untuk menguji fungsionalitas sistem, dan uji pemakaian untuk menguji apakah sistem sudah layak untuk digunakan. Apabila masih terdapat error pada aplikasi, maka peneliti akan melakukan coding perbaikan. Apabila aplikasi sudah berjalan dengan baik, maka aplikasi telah selesai dan siap digunakan.

\section{Hasil dan Pembahasan}

Perancangan sebuah sistem berbasis komputer analisa memegang peran yang sangat penting dalam membuat rincian sistem. Analisa perangkat lunak merupakan langkah pemahaman persoalan sebelum mengambil tindakan atau keputusan penyelesaian hasil utama. Sedangkan tahap perancangan sistem adalah membuat rincian sistem dari hasil analisis menjadi bentuk perancangan agar dimengerti oleh pengguna.Keberhasilan suatu sistem pakar terletak pada pengetahuan dan bagaimana mengolah pengetahuan tersebut agar dapat ditarik suatu kesimpulan. Pengetahuan yang diperoleh dari hasil wawancara dan analisa lewat buku dikonversi kedalam sebuah tabel penyakit dan gejala guna mempermudah proses pencarian solusi. Tabel jenis penyakit dan gejala ini digunakan sebagai pola pencocokan informasi yang dimasukan oleh pemakai dan basis pengetahuan.

\begin{tabular}{|c|c|}
\hline Penyakit & Gejala \\
\hline \multirow{3}{*}{$\begin{array}{l}\text { Rebah semai } \\
\text { (Phytium sp.) }\end{array}$} & Fusarium menyerang pangkal batang tanaman. \\
\hline & $\begin{array}{l}\text { Fusarium ditandai dengan layunya tanaman } \\
\text { dimulai dari bagian bawah tanaman dan menjalar hingga ke atas tanaman. }\end{array}$ \\
\hline & $\begin{array}{l}\text { Pada pangkal batang terdapat bercak memanjang kuning dan coklat tua. Jika } \\
\text { batang tersebut dipotong terdapat cincin coklat pada berkas pembuluh. }\end{array}$ \\
\hline \multirow{2}{*}{$\begin{array}{l}\text { Layu fusarium } \\
\text { (Fusarium ox } \\
\text { ysporum) }\end{array}$} & $\begin{array}{l}\text { Fusarium ditandai dengan layunya tanaman dimulai dari bagian bawah tanaman } \\
\text { dan menjalar hingga ke atas tanaman. }\end{array}$ \\
\hline & $\begin{array}{l}\text { Pada pangkal batang terdapat bercak memanjang kuning dan coklat tua. Jika } \\
\text { batang tersebut dipotong terdapat cincin coklat pada berkas pembuluh. }\end{array}$ \\
\hline \multirow{2}{*}{$\begin{array}{l}\text { Layu Bakteri } \\
\text { (Erwinia trac } \\
\text { heiphila) }\end{array}$} & Tanaman layu mendadak dan mati. \\
\hline & Jika batang tanaman dipotong, berkas pembuluh angkut berlendir. \\
\hline \multirow{3}{*}{$\begin{array}{c}\text { Downy Mildew } \\
\text { (Pseudopero nospora } \\
\text { cub ensis) }\end{array}$} & Penyakit kresek. \\
\hline & Permukaan daun terlihat bercak kuning coklat. \\
\hline & Pada bawah daun terdapat spora berwarna ungu sampai hitam. \\
\hline \multirow{3}{*}{$\begin{array}{c}\text { Powdery Mildew } \\
\text { (Erysiphe cic } \\
\text { horacearum) }\end{array}$} & $\begin{array}{l}\text { Permukaan atas daun terdapat tepung serbuk spora putih. Serangannya berasal dari } \\
\text { bawah dan berkembang ke atas hingga menutupi permukaan daun. }\end{array}$ \\
\hline & Fusarium menyerang pangkal batang tanaman. \\
\hline & Permukaan daun terlihat bercak kuning coklat. \\
\hline \multirow{4}{*}{$\begin{array}{l}\text { Cucumber Mozaik } \\
\quad \text { Virus (CMV) }\end{array}$} & Tanaman layu mendadak dan mati. \\
\hline & Daun terlihat belang hijau tua dan muda (hingga kekuningan). \\
\hline & Daun mengkerut. \\
\hline & Tepi daun menggulung dan tanaman kerdil. \\
\hline
\end{tabular}

Tabel 2. Range Presentase Hasil

Tabel 3. Basis Aturan

Rule $\quad$ Kondisi




\begin{tabular}{|l|l|l|l|}
\hline $\begin{array}{l}\text { N } \\
\mathrm{o}\end{array}$ & $\begin{array}{l}\text { Nilai } \\
\text { Bobo } \\
\mathrm{t} \\
\text { Gejal } \\
\mathrm{a}\end{array}$ & $\begin{array}{l}\text { Persenta } \\
\text { se Nilai } \\
\text { Densitas }\end{array}$ & $\begin{array}{l}\text { Keteranga } \\
\mathrm{n}\end{array}$ \\
\hline 1 & 0.25 & $<50 \%$ & $\begin{array}{l}\text { Kurang } \\
\text { Pasti }\end{array}$ \\
\hline 2 & 0.5 & $\begin{array}{l}50 \%- \\
59 \%\end{array}$ & $\begin{array}{l}\text { Cukup } \\
\text { Pasti }\end{array}$ \\
\hline 3 & 0.75 & $\begin{array}{l}60 \%- \\
69 \%\end{array}$ & Pasti \\
\hline 4 & 1 & $\begin{array}{l}70 \%- \\
100 \%\end{array}$ & $\begin{array}{l}\text { Sangat } \\
\text { Pasti }\end{array}$ \\
\hline
\end{tabular}

\begin{tabular}{|l|l|}
\hline $\begin{array}{l}\text { Rule } 1 \\
(R 1)\end{array}$ & IF G1 AND G2 AND G3 = YES THEN P1 \\
\hline $\begin{array}{l}\text { Rule } 2 \\
(R 2)\end{array}$ & IF G2 AND G3 = YES THEN P2 \\
\hline $\begin{array}{l}\text { Rule } 3 \\
(R 3)\end{array}$ & IF G4 AND G5 = YES THEN P3 \\
\hline $\begin{array}{l}\text { Rule } 4 \\
(R 4)\end{array}$ & IF G6 AND G7 AND G8 = YES THEN P4 \\
\hline $\begin{array}{l}\text { Rule } 5 \\
(\text { R5 })\end{array}$ & IF G1 AND G7 AND G9 = YES THEN P5 \\
\hline $\begin{array}{l}\text { Rule 6 } \\
(\text { R6 })\end{array}$ & IF G4 AND G10 AND G11 AND G12 = YES \\
\hline
\end{tabular}

Metode yang digunakan penulis agar kebutuhan pengguna dapat dipenuhi yaitu dengan menggunakan metode Dempster Shafer. Dempster shafer adalah suatu teori matematika untuk pembuktian berdasarkan belif functions and plausible reasoning ( fungsi kepercayaan dan pemikiran yang masuk akal), yang digunakan untuk mengkombinasikan potongan informasi yang terpisah (bukti) untuk mengkalkulasi kemungkinan dari suatu peristiwa.

1. Menghitung nilai Metode Dempster Shafer

Berdasarkan perumusan pada BAB I diatas penelitian ini hanya berfokus pada 6 (enam) jenis penyakit tanaman mentimun yaitu Rebah semai, Layu fusarium, Layu Bakteri, Downy Mildew, Powdery Mildew, Cucumber Mozaik Virus. Contoh gejala yang dialami oleh tanaman mentimun adalah sebagai berikut Fusarium menyerang pangkal batang tanaman (G1), Fusarium ditandai dengan layunya tanaman dimulai dari bagian bawah tanaman dan menjalar hingga ke atas tanaman (G2), Tanaman layu mendadak dan mati (G4), Jika batang tanaman dipotong, berkas pembuluh angkut berlendir (G5) dan Permukaan daun terlihat bercak kuning coklat (G7).

Berikut adalah langkah untuk mendiagnosa penyakit pada tanaman mentimun dengan menggunakan metode Dempster Shafer:

1. Gejala $1 \Rightarrow \mathrm{G} 1=$ Fusarium menyerang pangkal batang tanaman

$\mathrm{m}_{1}(\mathrm{P} 1, \mathrm{P} 5) \quad=0.9$

$\mathrm{m}_{1}(\Theta)=1-\mathrm{m}_{1}$

$\mathrm{m}_{1}(\Theta) \quad=1-0.9=0.1$

2. Gejala $2 \Rightarrow \mathrm{G} 2$ = Fusarium ditandai dengan layunya tanaman dimulai dari bagian bawah tanaman dan menjalar hingga keatas tanaman.

$$
\begin{aligned}
& \mathrm{m}_{2}(\mathrm{P} 1, \mathrm{P} 2)=0.8 \\
& \mathrm{~m}_{2}(\Theta)=1-\mathrm{m}_{2} \\
& \mathrm{~m}_{2}(\Theta)=1-0.8=0.2
\end{aligned}
$$

Menghitung kembali nilai densitas baru untuk setiap himpunan bagian fungsi dengan fungsi densitas $\mathrm{m}_{3}$. Aturan kombinasi untuk $\mathrm{m}_{3}$

3. Gejala $3=>\mathrm{G} 4=$ Tanaman layu mendadak dan mati.

$$
\begin{aligned}
& \mathrm{m}_{4}(\mathrm{P} 3, \mathrm{P} 6)=0.9 \\
& \mathrm{~m}_{4}(\Theta)=1-\mathrm{m}_{4} \\
& \mathrm{~m}_{4}(\Theta)=1-0.9=0.1
\end{aligned}
$$

Menghitung kembali nilai densitas baru untuk setiap himpunan bagian fungsi dengan fungsi densitas $\mathrm{m}_{5}$.

4. Gejala $4 \Rightarrow$ G5 = Jika batang tanaman dipotong, berkas pembuluh angkut berlendir.

$$
\begin{array}{ll}
\mathrm{m}_{6}(\mathrm{P} 3) & =0.7 \\
\mathrm{~m}_{6}(\Theta) & =1-\mathrm{m}_{6} \\
\mathrm{~m}_{6}(\Theta) & =1-0.7=0.3
\end{array}
$$

Menghitung kembali nilai densitas baru untuk setiap himpunan bagian fungsi dengan fungsi densitas $\mathrm{m}_{7}$.

1. Gejala $5=>\mathrm{G} 7=$ Permukaan daun terlihat bercak kuning coklat.

$\mathrm{m}_{8}(\mathrm{P} 3)=0.7$

$\mathrm{m}_{8}(\theta) \quad=1-\mathrm{m}_{8}$

$\mathrm{m}_{8}(\Theta)=1-0.7=0.3$

Menghitung kembali nilai densitas baru untuk setiap himpunan bagian fungsi dengan fungsi densitas $\mathrm{m}_{9}$. Aturan kombinasi untuk $m_{9}$ adalah sebagai berikut :

Tabel 4. Aturan Kombinasi 
Penjelasan :

\begin{tabular}{|l|c|c|c|c|c|}
\hline \multicolumn{2}{|c|}{$\mathrm{m}_{7}$} & \multicolumn{4}{c|}{$\mathrm{m}_{8}$} \\
\cline { 3 - 6 } & $\mathrm{m}_{8}(\mathrm{P} 4, \mathrm{P} 5)$ & 0,7 & $\mathrm{~m}_{8}(\Theta)$ & 0,3 \\
\hline $\mathrm{m}_{7}(\mathrm{P} 6)$ & 0,255 & \{\} & 0,179 & $\mathrm{P} 6$ & 0,077 \\
\hline $\mathrm{m}_{7}(\mathrm{P} 3)$ & 0,028 & \{\} & 0,020 & $\mathrm{P} 3$ & 0,009 \\
\hline $\mathrm{m}_{7}(\mathrm{P} 3, \mathrm{P} 6)$ & 0,109 & \{\} & 0,077 & $\mathrm{P} 3, \mathrm{P} 6$ & 0,033 \\
\hline $\mathrm{m}_{7}(\mathrm{P} 1)$ & 0,437 & \{\} & 0,306 & $\mathrm{P} 1$ & 0,131 \\
\hline $\mathrm{m}_{7}(\mathrm{P} 1, \mathrm{P} 2)$ & 0,049 & \{\} & 0,034 & $\mathrm{P} 1, \mathrm{P} 2$ & 0,015 \\
\hline $\mathrm{m}_{7}(\mathrm{P} 1, \mathrm{P} 5)$ & 0,109 & $\mathrm{P} 5$ & 0,077 & $\mathrm{P} 1, \mathrm{P} 5$ & 0,033 \\
\hline $\mathrm{m}_{7}(\mathrm{O})$ & 0,012 & $\mathrm{P} 4, \mathrm{P} 5$ & 0,009 & $\Theta$ & 0,004 \\
\hline
\end{tabular}

$\mathrm{m}_{7}(\mathrm{P} 6) \times \mathrm{m}_{8}(\mathrm{P} 4, \mathrm{P} 5)=\{\}$

$\mathrm{m}_{7}(\mathrm{P} 3) \times \mathrm{m}_{8}(\mathrm{P} 4, \mathrm{P} 5)=\{\}$

$\mathrm{m}_{7}(\mathrm{P} 3, \mathrm{P} 6) \times \mathrm{m}_{8}(\mathrm{P} 4, \mathrm{P} 5)=\{\}$

$\mathrm{m}_{7}(\mathrm{P} 1) \times \mathrm{m}_{8}(\mathrm{P} 4, \mathrm{P} 5)=\{\}$

$\mathrm{m}_{7}(\mathrm{P} 1, \mathrm{P} 2) \times \mathrm{m}_{8}(\mathrm{P} 4, \mathrm{P} 5)=\{\}$

$\mathrm{m}_{7}(\mathrm{P} 1, \mathrm{P} 5) \times \mathrm{m}_{8}(\mathrm{P} 4, \mathrm{P} 5)=\mathrm{P} 5$

$\mathrm{m}_{7}(\Theta) \times \mathrm{m}_{8}(\mathrm{P} 4, \mathrm{P} 5)=\mathrm{P} 4, \mathrm{P} 5$

Sehingga diperoleh :

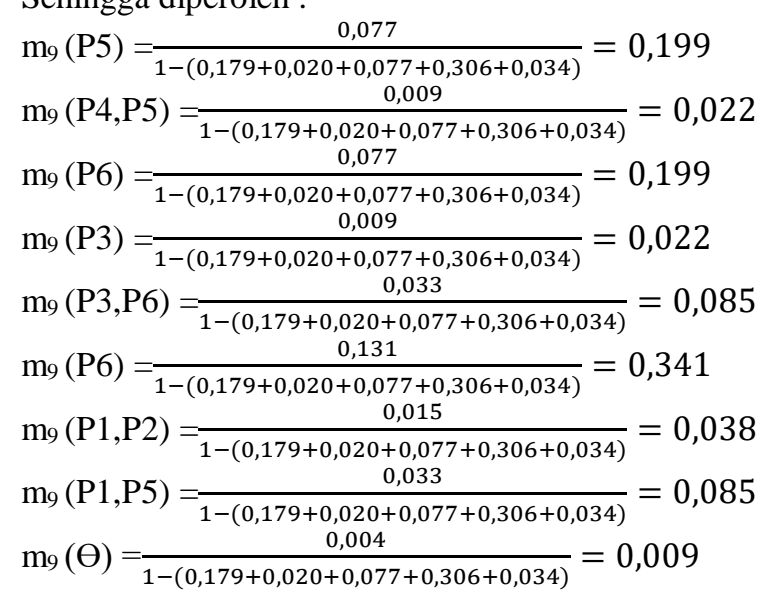

Dari hasil perhitungan gejala yang terakhir diperoleh nilai densitas tertinggi yaitu $\mathrm{m}_{9}(\mathrm{P} 6)$ dengan nilai 0.341 atau dengan persentasi sebesar $34 \%$.

Sedangkan dari seluruh perhitungan dengan menggunakan metode Dempster Shafer sesuai degan Gejala G1, G2, G4, G5, G7 diperoleh nilai densitas tertinggi yaitu $\mathrm{m}_{5}(\mathrm{P} 6)$ dengan nilai densisat sebesar 0.610 atau sebesar $61 \%$.

Maka dapat diambil kesimpulan bahwa mentimun terjangkit penyakit Cucumber Mozaik Virus (CMV) (P6).

Tabel 5. Hasil Perhitungan

\begin{tabular}{|c|l|c|c|c|}
\hline No & \multicolumn{1}{|c|}{ Gejala } & Nilai Densitas & Persentase Nilai Densitas & Keterangan \\
\hline 1 & $\mathrm{~m}_{5}(\mathrm{P} 6)$ & 0.610 & $61 \%$ & Pasti \\
\hline 2 & $\mathrm{~m}_{9}(\mathrm{P} 6)$ & 0,199 & $19 \%$ & Kurang Pasti \\
\hline 3 & $\mathrm{~m}_{9}(\mathrm{P} 4, \mathrm{P} 5)$ & 0,022 & $2 \%$ & Kurang Pasti \\
\hline 4 & $\mathrm{~m}_{9}(\mathrm{P} 6)$ & 0,199 & $19 \%$ & Kurang Pasti \\
\hline 5 & $\mathrm{~m}_{9}(\mathrm{P} 3)$ & 0,022 & $2 \%$ & Kurang Pasti \\
\hline 6 & $\mathrm{~m}_{9}(\mathrm{P} 3, \mathrm{P} 6)$ & 0,085 & $8 \%$ & Kurang Pasti \\
\hline 7 & $\mathrm{~m}_{9}(\mathrm{P} 1)$ & 0,341 & $34 \%$ & Kurang Pasti \\
\hline
\end{tabular}




\begin{tabular}{|l|l|l|l|l|}
\hline 8 & $\mathrm{~m}_{9}(\mathrm{P} 1, \mathrm{P} 2)$ & 0,038 & $3 \%$ & Kurang Pasti \\
\hline 9 & $\mathrm{~m}_{9}$ (P1,P5) & 0,085 & $8 \%$ & Kurang Pasti \\
\hline
\end{tabular}

Pengujian merupakan hal terpenting yang bertujuan untuk mengetahui kemampuan perangkat lunak (Android Programming) dalam melihat apakah sistem yang dibangun sudah menghasilkan output yang sama pada perhitungan.

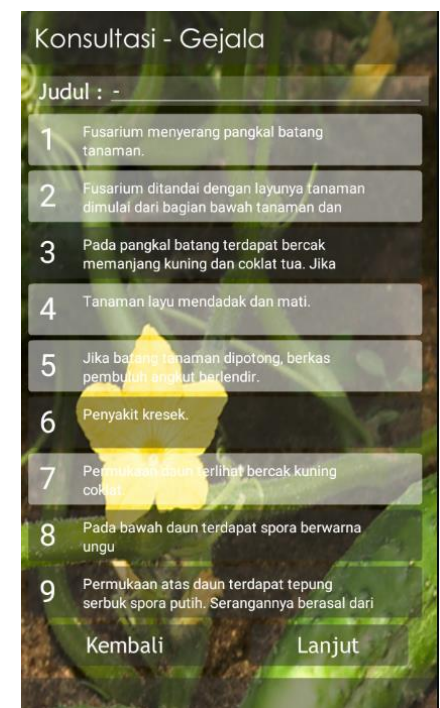

Gambar 1. Halaman Konsultasi Gejala

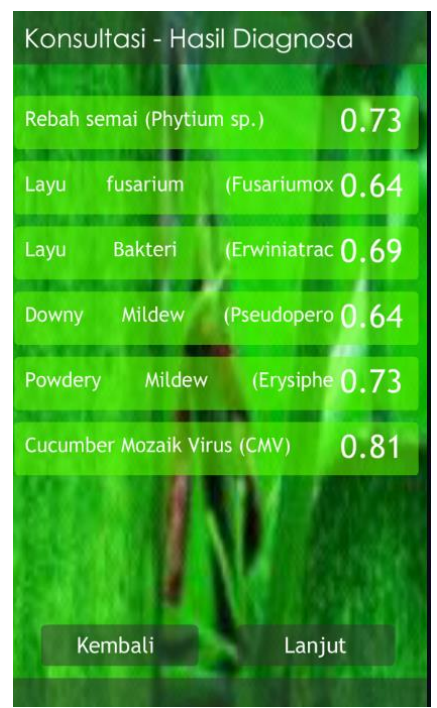

Gambar 2. Halaman Hasil Dagnosa

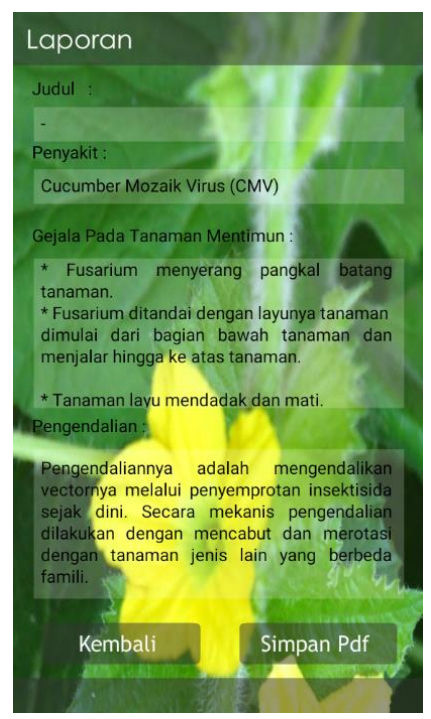

Gambar 3. Halaman Laporan

\section{Kesimpulan}

Kesimpulan dari penelitian :

1. Aplikasi dapat digunakan untuk menentukan penyakit apa yang sedang menyerang serta pengendaliannya dan dengan perhitungan yang cepat dan tepat.

2. Sistem hanya dapat menganalisa berdasarkan data-data yang sudah ditentukan.

3. Penerapan metode Dempster Shafer memberikan suatu keputusan pengendalian berdasarkan dari hasil perhitungan nominal tertinggi. Berdasarkan rancangan maka aplikasi tersebut dapat digunakan untuk membantu petani dalam pengendalian penyakit pada tanaman mentimun. Berdasarkan hasil rancangan maka aplikasi sistem pakar dapat di implementasikan dengan menggunakan metode Dempster Shafer.

\section{Daftar Pustaka}

[1] N. S. W. Ginting and A. S. R. Sinaga, "Sistem Pakar Diagnosa Penyakit Kacang Kedelai Menggunakan Metode Certainty Factor,” UPI YPTK J. KomTekInfo, vol. 5, no. 1, pp. 36-41, 2018.

[2] D. Purnomo, B. Irawan, and Y. Brianorman, "Jurnal Coding Sistem Komputer Untan Jurnal Coding Sistem Komputer Untan ISSN : 2338-493X,” Sist. Pakar Diagnosa Penyakit Pada Kucing Menggunakan Metod. Demster-Shafer Berbas. Android, vol. 05, no. 1, pp. 45-55, 2017.

[3] D. Purnomo, B. Irawan, and Y. Brianorman, "Sistem Pakar Diagnosa Penyakit Pada Kucing Menggunakan Metode Dempster-Shafer Berbasis Android,” J. Coding Sist. Komput. Untan, vol. 05, no. 1, pp. 23-32, 2017.

[4] H. Setiawan, "SISTEM PAKAR IDENTIFIKASI JENIS VIRUS PADA KOMPUTER," vol. 2, pp. 123-130, 2019.

[5] U. Kristen and K. Wacana, "PERANCANGAN SISTEM PAKAR DIAGNOSIS PENYAKIT GINJAL MENGGUNAKAN METODE DEMPSTER-SHAFER BERBASIS WEBSITE JISICOM ( Journal of Information System , Informatics and Computing ) p-ISSN : 2579-5201 ( Printed ) JISICOM ( Journal of Information System , Informatics and Computing ),” vol. 4, no. 1, pp. 107$115,2020$.

[6] I. Rahayu et al., "Perancangan sistem pakar diagnosa penyakit pada bayi menggunakan metode 
dempster shafer," vol. 2, no. 2, pp. 222-231, 2020.

[7] Suhendro and N. Sevani, "Penerapan Metode Dempster-Shafer untuk Deteksi Penyakit Demam Berdarah dan Tipus," Tek. dan Ilmu Komput., vol. 7, no. 28, pp. 459-471, 2018.

[8] A. Arifsyah and A. Sindar, "Sistem Pakar Diagnosa Penyakit Pohon Karet Dengan Metode Certainty Factor,” J. Nas. Komputasi dan Teknol. Inf., vol. 2, no. 2, p. 175, 2019, doi: 10.32672/jnkti.v2i2.1568.

[9] M. Handayani and Taufiq, "Sistem Pakar Diagnosa Penyakit Tanaman Semangka Menggunakan Metode Dempster Shafer Berbasis Web," J. Progresif, vol. 13, no. 2, pp. 1727-1734, 2017.

[10] R. T. Waruwu and A. Sindar, "SISTEM PAKAR MENENTUKAN JENIS GANGGUAN PERKEMBANGAN ANAK MENGGUNAKAN METODE CERTAINTY FACTOR,” vol. 2, no. 2, pp. 35-41, 2019.

[11] M. Widyaningsih, R. Gunadi, J. T. Informatika, and K. Tengah, "Dempster shafer untuk sistem diagnosa. jurnal/282-37-464-1-10-20180810.pdfa penyakit kulit pada kucing,” vol. 7, no. 114, 2017. 